9. Субина М.Ю. П.В. Анненков и В.А. Панов переписчики Гоголя // Вестник Ленинского мемориала. Вып. 12: мат-лы межрегиональной науч. конф. «Павел Васильевич Анненков (1812-1887). К 200летию со дня рождения». 21 июня 2012 г. Ульяновск: Корп. технологий продвижения, 2012. С. 35-40.

10. Ушанова Ю.В. «Начинатель науки славянской» (В.А. Панов - литератор, историк-славист, издатель-редактор) // Страницы культурной жизни Симбирской губернии - Ульяновской области: сб. мат-лов межрегион. науч.-практ. конф. Ульяновск: ИП Василькина М.Н., 2012. С. 117-119.

11. Буслаев Ф.И. Из «Моих воспоминаний» // Гоголь в воспоминаниях современников. М.: Гос. издво худ. лит-ры, 1952. С. 223-224.

12. Панов В.А. Путешествие по землям западных и южных славян. Ч. 1. Которский округ в Далмации. M., 1844.

13. Панов В.А. Очерк Черногорской истории // Библиотека для воспитания. М., 1845. Ч. 3.

14. Панов В.А. О настоящих жилищах южных и западных славян и их расселении в Европе // Библиотека для воспитания. М., 1845. Ч. 4.
15. Панов В.А. История хорватов // Библиотека для воспитания. М., 1845. Ч. 5.

16. Панов В.А. История Болгарского государства // Библиотека для воспитания. М., 1845. Ч. 6.

17. Синбирский сборник. Часть историческая. T. 1. M., 1844.

18. Московский литературный и ученый сборник. M., 1846.

19. Московский литературный и ученый сборник на 1847 год. М., 1847.

20. Иван Сергеевич Аксаков в его письмах. Часть первая. Учебные и служебные годы. Том первый. Письма 1839-1848 годов. М., 1888.

21. Сочинения и письма Н.В. Гоголя. Т. VI. Письма с 1843 по 1852 год. Издание П.А. Кулиша. СПб., $1857.567 \mathrm{c}$.

22. Государственный архив Ульяновской области (далее - ГАУО). Ф. 270. Оп. 2. Д. 7.

23. ГАУО. Ф. 270. Оп. 2. Д. 8.

24. ГАУО. Ф. 270. Оп. 2. Д. 3.

25. ГАУО. Ф. 270. Оп. 2. Д. 4.

26. ГАУО. Ф. 270. Оп. 2. Д. 30.

\title{
PORTRAIT OF THE LANDOWNER AND SLAVOPHIL V.A. PANOV
}

(C) 2017

Sudakov Mikhail Alexandrovich, candidate of historical sciences, associate professor of Humanities and Social Sciences Department; senior researcher of Archaeology Department Ulyanovsk Institute of Civil Aviation named after Chief Marshal of Aviation B.P. Bugaev; Research Institute of History and Culture of Ulyanovsk Region named after N.M. Karamzin (Ulyanovsk, Russian Federation)

Abstract. The purpose of this paper is to analyze V.A. Panov's activities. He was one of the early representatives of Slavophilism. His biography is of great interest in the context of the Russian social thought history. The author characterizes V.A. Panov's main activities in scientific, editorial and publishing fields. The author also shows his cooperation with N.V. Gogol. It is shown that the most important aspect of V.A. Panov's activities was his work on two editions of the Slavophil anthology «The Moscow literary and scientific collection». This edition brought together almost all prominent representatives of this social thought and caused a considerable resonance. The author's use of the Ulyanovsk Region state archive materials helped to portray the personality of the landowner Panov in his family history. The copies of charters, studied by the author, show that the consolidation of the economic positions of the Panovs' family in the Volga region dates back to the 17th century. This process was associated with the active participation of V.A. Panov's ancestors in the fighting on the side of the Tsardom of Muscovy against the Polish Prince Vladislav during the Russo-Turkish war 1672-1681. V.A. Panov owned lands in three provinces (Simbirsk province, Penza province, and Nizhny Novgorod province). A notable fact of his economic activity was his participation in the holding of a special land survey.

Keywords: V.A. Panov; Slavophilism; social thought; N.V. Gogol; Balkan peoples; «Sinbirskiy collection»; D.A. Valuev; «the Moscow literary and scientific collection»; «Serbian folk songs»; patrimony; estate; Simbirsk province; Penza province; Nizhny Novgorod province; Anastasovo; special land survey.

УДК 930

\section{РОЛЬ ГОСУДАРСТВЕННЫХ ОРГАНОВ ВЛАСТИ В ОРГАНИЗАЦИИ ГОСУДАРСТВЕННОГО ПРОСВЕЩЕНИЯ В СИМБИРСКОЙ ГУБЕРНИИ ВО ВТОРОЙ ПОЛОВИНЕ ХІХ ВЕКА}

(C) 2017

\author{
Айзатуллова Алсу Шамилевна, кандидат исторических наук, \\ доцент кафедры гуманитарных и социальных дисциплин \\ Ульяновский институт гражданской авиаџии имени Главного маршала авиации Б.П. Бугаева \\ (2. Ульяновск, Российская Федераиия)
}

\begin{tabular}{l} 
Аннотация. В данной статье рассматривается роль государственных органов власти в организации госу- \\
арственного просвещения населения Симбирской губернии во второй половине ХІХ - начале ХХ в. Рас- \\
смотрены государственные структуры, которые совместно с Русской православной церковью, другими кон- \\
ессиями руководили всем делом государственно-религиозного просвещения в стране. Исследуется роль \\
гсударственных органов власти в организации государственно-религиозного просвещения населения края. \\
\hline 44 Самарский научный вестник. 2017. Т. 6, № 2(19)
\end{tabular} 
В масштабах государства организациями, ответственными за него, являлись Министерство народного просвещения и Святейший синод, на местах данную работу координировали попечительства учебных округов, дирекции народного образования, а также губернские и уездные советы.

В светских образовательных учреждениях просветительскую работу организовывали дирекции народных училищ, которые контролировали просветительскую работу школьных педагогов и использование действенных форм и методов. Основными направлениями в деятельности дирекций народного образования было устройство совместных русско-татарских школ, открытие русских классов в исламских школах и введение обязательного изучения русского языка в татарских школах. Немаловажной целью было ужесточение контроля за деятельностью школ. Существовали православные миссионерские братства. Эти, во многом дублирующие друг друга учреждения, занимались, по сути, одними и теми же вопросами. Губернские дирекции народного образования были вынуждены координировать всю государственно-просветительскую работу, проводимую учителями, конфессиональными священниками, миссионерами.

Таким образом, сама система управления государственно-религиозным просвещением была сложна, разнообразна, ее звенья копировали друг друга - следовательно, это приводило к снижению эффективности ее деятельности.

Ключевые слова: просвещение; губернские дирекции; Святейший Синод; верноподданнический дух; государственные органы власти; Министерство народного просвещения; попечительства учебных округов; губернские и уездные училищные советы; епархии; конфессии; дирекция народного образования; церковноприходские; светские школы; православные миссионерские братства.

Высшими государственными органами при императорах были Государственный совет, Собственная Его Императорского Величества канцелярия, Комитет министров, Сенат, Синод, различные комитеты и канцелярии, которые в той или иной степени были ответственными за проведение просветительской деятельности. Государственный совет сохранил значение высшего законосовещательного органа, члены которого назначались царем из высших, часто отставных чиновников и министров. В нем обсуждались многие законопроекты и реформы. С 1884 года Государственный совет контролировал решения Сената. Государственным Советом были приняты некоторые решения, тем или иным образом соприкасавшиеся с государственно-просветительской деятельностью. Важную роль в организации просветительской деятельности играл Комитет министров, который оставался высшим административным учреждением без достаточно четких функций, то есть совещательным органом при монархе с наиболее доверенными чиновниками, через которых царская администрация претворяла в жизнь свои решения. Совет министров (1861-1882 гг.) заслушивал годовые отчеты министров, согласовывал деятельность ведомств, обсуждал мероприятия по осуществлению реформ. Именно Совет Министров принимал некоторые важные постановления по организации государственнорелигиозного просвещения, которые немедленно принимали силу закона.

Немалый вклад в организацию государственнорелигиозного просвещения населения империи внес Святейший синод. По своему значению и устройству он был ближе к министерству, чем к высшему учреждению. В то же время обер-прокурор Синода иногда играл важную роль в политической жизни страны. Например, одним из вдохновителей контрреформ был К.П. Победоносцев. Святейший Синод активно занимался православным просвещением, направляя в решении этого вопроса деятельность епархий. Его аппарат разрабатывал учебные программы для церковно-приходских школ, церковных приютов и богаделен, программы для изучения учебной дисциплины «Закон Божий» для светских школ, контролировал подготовку педагогов из числа православных священников и светских лиц.
Правительство в основном требовало организовывать работу по общественно-государственному и православному просвещению от губернских училищных советов и дирекций народного образования. Система управления начальным и народным образованием сформировалась в основном согласно указаниям, изложенным в «Положении о начальных народных училищах» 1864 года. Все управленческие указания в губернии шли от руководства Казанского учебного округа.

В Симбирской губернии, как и в других регионах, главным коллегиальным органом был Губернский училищный совет. В 1897 году по ходатайству обществ крестьян Симбирский уездный училищный совет открыл целую сеть начальных народных школ [1]. Однако полицейский надзор за системой народного образования не только не ослаб, но еще более усилился, свидетельством чему является появление новой формы надзора - запросы, направляемые уездными и губернскими советами Симбирской губернии в жандармское управление о благонадежности не только учителей, но и аппаратных работников советов [2].

В уездах также создавались училищные советы. Председателем совета был уездный архиерей, членами советов - уездные инспектора народных училищ и несколько представителей от уездного земства. Обязанности уездных училищных советов отличались от губернского. В первую очередь уездные советы наблюдали за преподаванием всех предметов (кроме «Закона Божьего», надзор за которым осуществляла непосредственно епархия), за открытием новых училищ [3, с. 102], улучшением ранее открытых, контролем над снабжением народных училищ учебными пособиями.

В Симбирской губернии с 1869 года существовал также аппарат директора народных училищ, который включал в свой состав несколько инспекторов (сначала по одному, затем по два на каждый уезд). До 1869 года начальными народными училищами руководил в Симбирской губернии инспектор народных училищ, затем была введена должность директора народных училищ, в подчинение у которого находи- 
лись уже несколько инспекторов. Немаловажное значение имел также институт попечительства по делам народного образования. В попечительские советы, создаваемые в волостях и уездах, входили избранные на эти должности лица, законоучителя, представители земств, выборные от местного населения. Им отводилась роль в решении следующих вопросов: снабжение школы учебниками, обеспечение транспортом школьников, добирающихся в школу из дальних сел. Они также занимались оказанием начальной школе денежной помощи, для чего попечителям разрешалось собирать пожертвования, устраивать для этих целей концерты, публичные чтения. Попечительство до 1907 года не было регламентировано никакими документами, лишь 26 марта этого же года вышло «Положение о попечительствах», где эти вопросы были регламентированы.

Положение 1864 года утвердило и структуру начальных школ, к которым относились следующие учебные заведения:

- приходские и начальные училища, подчиненные Министерству народного просвещения (содержащиеся за счет местных обществ и частично за счет казны, а также на пожертвования частных лиц);

- сельские училища, а также училища, подчиненные другим ведомствам (Министерство Государственного Имущества, МВД, удельного, горного, военного и др.);

- церковно-приходские училища;

- воскресные школы [4].

«Положение о народных училищах» 1874 года внесло свои коррективы в систему управления. В начале 80-х годов были выработаны критерии подхода к подбору учебной литературы. Для того чтобы использовать какое-либо учебное пособие на занятии, необходимо было одобрение Министерства народного просвещения, Святейшего Синода. Особо хочется остановиться на работе дирекции народного образования Симбирской губернии в рассматриваемый период. Длительное время ее возглавлял известный педагог И.Н. Ульянов. Благодаря его стараниям, а также деятельности его преемников управление начальным народным образованием в губернии было поставлено на высокий уровень.

Дирекция народного образования принимала самое активное участие в просвещении коренных народов края. Чтобы лучше понять сам механизм воздействия членов Дирекции народного образования на образовательные процессы нерусских народов, достаточно обратиться к деятельности одного из активнейших членов этого общества И. Яковлева инспектора чувашских народных училищ в Симбирской губернии. Вот один из примеров, приведенных исследователем Н.Х. Юмакуловым. На одном из заседаний в 1896 году И. Яковлев выступил с тревожной информацией о том, что в Средне-Алгашинской волости Симбирской губернии местные представители чувашского народа оказались под сильным влиянием своих соседей - татар, оказались сильно восприимчивы к проповеднической деятельности мулл. В результате этого начался повальный переход многих представителей чувашского населения из право- славия в ислам. И.Я. Яковлев предложил членам совета выделить денежные средства для открытия в Средне-Алгашинской волости сети миссионерских школ православной направленности для активного противодействия этому процессу. Симбирский училищный совет охотно пошел навстречу просьбе И.Я. Яковлева и выделил ему на эти цели 1220 рублей. После открытия «противомусульманской» миссионерской чувашской школы процесс перехода чувашей в ислам в этой волости был приостановлен [5, c. 53].

Усилиями И.Я. Яковлева и его сподвижников в Симбирской губернии по состоянию на 1 января 1897 года в 3-х классной Симбирской чувашской учительской школе училось 102 ученика, из них русских -25 , чувашей -75 , мордвы -2 . Одновременно в школе при училище обучалось 78 детей, из них 71 чуваш и 7 русских. Дирекция народных училищ проводила активную работу по созданию и руководству деятельностью «школ грамоты». Как правило, это были учреждения миссионерской направленности. В 1896 году «школы грамоты» закончили успешно 160 детей, которые, согласно отчету И.Я. Яковлева, «воспитаны в церковном духе». Небезынтересен опыт Трехизбинской церковно-приходской «школы грамоты», которая также действовала под присмотром И.Я. Яковлева. Все выпускники этой школы продемонстрировали удовлетворительные знания Закона Божьего, арифметики и русского языка, что говорило о довольно высоком уровне преподавания. Подобные «школы грамоты» в массовом количестве создавались в уездах [6].

Проведенное исследование не позволило выявить каких-либо специальных структур в епархиальном руководстве, предназначенных для этих целей. Считалось, что дохристианская религия особой угрозы для нравственности не представляет, однако на рубеже XIX-XX вв. участились случаи вероотступничества со стороны коренных народов Симбирской губернии - чувашей и мордвы.

На противоязыческое религиозно-нравственное воспитание в Симбирской губернии также выделялись значительные финансовые средства. Одновременно в районе были построены церкви. Постепенно языческое население края, как русские, так и «инородцы», таких деревень, как Большая Акса, Богдашкино, Верхние Темирсяны, Новые Чукалы, все больше и больше стали приобщаться к православной веpe.

Процесс приобщения к православной культуре несколько затянулся в деревне Старо-Чекурской. Православно-церковная школа вначале не приобрела здесь необходимой популярности. Учителям и священнику пришлось вначале заручиться поддержкой стариков-чувашей, которые, в свою очередь, убедили односельчан выделить деньги на строительство школы. После того, как необходимые средства были созданы, в 1909 году здание школы было построено, начался процесс возвращения населения в лоно православной веры [7].

Одним из направлений в деятельности Симбирской дирекции народного образования было устрой- 
ство совместных русско-татарских школ, которые начали появляться в Симбирской губернии при активной поддержке губернского и уездного руководства. Первая из них была создана в деревне Петряска Курмышского уезда с 84 учениками. К 1874 году было уже 6 подобных школ, практически во всех уездах. Если школа в Петряске содержалась за счет казны, то остальные школы содержались преимущественно за счет татарских обществ. Как показали результаты исследования Н.Х. Юмакулова, первые русско-татарские школы, созданные в 60-80 гг. XIX века, содержались в сложных условиях. Это объяснялось всецело той незначительной финансовой поддержкой и незначительной государственной помощью, которую выделяли государственные органы и земства.

Первые русско-татарские школы находились, как правило, в «дымных» лачугах, не были в должной степени обеспечены учебными пособиями, в них отсутствовала какая-либо мебель, за исключением наспех сколоченных деревянных скамеек. Неоднократно были случаи, как, например, в той же деревне Петряска в 1873 году, когда под давлением исламского духовенства местные татары с угрозой совершения погрома требовали закрыть школы [5].

Массовые выступления татар-магометан произошли в 1888 году в деревне Уразово Карсунского уезда, когда они, подстрекаемые исламским духовенством, разгромили здесь русско-татарскую школу и изгнали учителя. Власти не стали раздувать конфликт и временно прекратили здесь всякие попытки создать русско-татарскую школу. Подобные выступления в этом же году прошли и в других деревнях. В селе Нечаево татары-мусульмане попросту сожгли вновь построенное здание, выступления прошли и в других селах [8].

Первая часть начатого в начале 70-х годов XIX в. эксперимента по созданию русско-татарских школ завершилась неудачей. Первые школы имели жалкий вид, денег на их финансирование практически не выделялось, а местное население на свои средства содержать их отказывалось. Здания, выделенные для совместных русско-татарских школ, были тесные, темные, слабо вентилируемые. Уровень преподавания в них был низким, в должном количестве отсутствовала необходимая учебная литература. Детей туда зачастую собирали насильно, при помощи полиции. Население отказывалось отправлять детей в эти школы, объясняя свое желание именно их неблагоустроенностью. В Карсунском уезде полноценные занятия удалось наладить только в русско-татарской Драгинской школе.

Успешно действующие русско-татарские школы существовали и в Сенгилеевском уезде. Проведенный анализ показывает, что совместные русскотатарские школы удалось создать только в тех уездах, где были малочисленные татарские диаспоры (Карсунский, Сенгилеевский, Симбирский) и где было относительно незначительно влияние исламского духовенства.

Таким образом, можно однозначно указать на то, что процесс открытия русских классов в исламских школах и введение обязательного изучения русского языка в татарских школах не всегда и не везде проходил гладко.

Другим важным направлением в просветительской деятельности Симбирской Дирекции народного образования было внедрение в татарских школах изучения русского языка, а также открытие русских классов в медресе и мектебе.

С 1872 года в мектебе и медресе Симбирской губернии вводится обязательное изучение русского языка. Лучшие ученики из этих школ определяются в удельные школы для углубленного изучения русского языка. Всего по состоянию на 1872 год количество татарских исламских школ, где преподавался русский язык, было следующим: Сенгилеевский уезд - 2, Сызранский - 1, Карсунский - 6, Ардатовский 1 [9]. Это говорило о том, что новшество приживалось с трудом, общее количество данных школ было мизерным. Затем выпускники этих школ должны были преподавать русский язык в медресе татарам. Этим учителям специальным решением правительства выплачивалось жалованье в 30-60 рублей в год [10]. То есть правительство поощряло финансово только те исламские училища, где вводилось преподавание русского языка. «Правила» поощряли открытие русских классов в медресе и мектебе, преподавателям русского языка также устанавливалась государственная пенсия [11].

Однако в Симбирской губернии, как показывает исследование Н.Х. Юмакулова, из этого начинания практически ничего не вышло. Все факты свидетельствовали о том, что идея не увенчалась успехом. В 99\% медресе и мектебе преподавание русского языка так и не удалось ввести. Это новшество встретило ожесточенное сопротивление не только со стороны мулл-учителей, но и со стороны рядовых членов исламских общин.

Лишь после выхода «Правил» правительство стало поощрять появление совместных русско-татарских школ, всецело финансируемых правительством. Они изначально создавались как новометодные, именно сюда направлялась основная масса выпускников Казанской татарской учительской школы В. Радлова [5].

В борьбе с язычеством, сектантством и старообрядчеством Дирекцией народных училищ Симбирской губернии нередко использовался административный ресурс. Известен конфликт между дирекцией народных училищ Симбирской губернии и старообрядческой общиной села Аскилы Сызранского уезда, произошедший в сентябре 1909 года. Здесь была одна из наиболее многочисленных старообрядческих общин в губернии. Ее лидеры без согласования с дирекцией народных училищ летом 1909 года открыли свою старообрядческую церковно-приходскую школу, где всего было 18 учеников. Многие перешли в эту самовольно открытую школу из земских училищ. Проведенная проверка ее деятельности показала, что учителя-старообрядцы воспитывали и обучали своих воспитанников в духе религиозной ненависти к православному «еретическому» христианству, воспитывали в детях фанатизм и изуверство. Чашу терпения 
жителей села переполнил факт, когда, проходя мимо земской начальной сельской школы, ученики-старообрядцы разбили в ней камнями стекла и обозвали ее учеников «антихристами». После подачи жителями села коллективной жалобы в уездную инспекцию народных училищ, по ее решению школа была немедленно закрыта полицией [12].

В ходе исследования установлено, что основной государственной организацией, на которую была возложена функция координации всей работы по государственному и религиозному просвещению, было Министерство народного просвещения, а также его региональные структуры - учебные округа и губернские дирекции народного образования. Немаловажное значение имел также институт попечительства по делам народного образования. В попечительские советы, создаваемые в волостях и уездах, входили избранные на эти должности лица, законоучителя, представители земств, выборные от местного населения.

В то же время работа дирекций и училищных советов по государственному и православно-религиозному просвещению коренных народов Симбирской губернии не всегда была успешной. Прежде всего, это слабая координирующая работа, отсутствие необходимых финансовых средств и нехватка «динамизма» в работе.

Важным средством государственного просвещения населения края была начальная общеобразовательная школа. В Симбирской губернии состав учащихся школ в основном однороден по вероисповеданию - 96,3\% православных, 90\% детей крестьянского сословия. Значительной разнородностью отличается этнический состав учащихся начальных школ: русских - 80,7\%, мордвы - 9,2\%, чувашей - $8,8 \%$, татар $-0,9 \%$ и прочих национальностей $-0,4 \%$.

Большую часть учащихся в начальных школах составляли: в Ардатовском уезде - мордва, в Алатырском уезде - чуваши, в Буинском и Курмышском уездах - татары [13, с. 82].

Значительное число учащихся - представителей коренных народов края (мордвы - 3578, чувашей 3439 и татар - 347) - вызвало к жизни ряд особых, так называемых «инородческих школ», часть которых в течение долгого времени имела свою собственную инспекцию. По состоянию на 1 января 1906 года в Симбирской губернии числилось 138 так называемых «инородческих» школ, из которых было 68 чувашских (из них 41 в Буинском уезде), $58-$ мордовских (21 в Ардатовском и 11 в Алатырском уездах), 9 татарских (все в Карсунском уезде), а также 3 эстонских. В чувашских и мордовских школах преподавание велось на родном языке, срок обучения в них был четырехлетний. В татарских и эстонских школах языком преподавания был русский, однако в них чтение и письмо преподавалось на родном языке, а церковнославянского языка вообще не было [13, с. 87].

Таким образом, существовали государственные структуры, которые совместно с Русской православной церковью и другими конфессиями руководили всем делом государственно-религиозного просвеще- ния в стране, однако эта деятельность никогда не была для них приоритетной. Наибольший вклад в просветительскую деятельность вносили дирекции народного образования, хотя эту службу они также не считали первостепенной, больше надеясь на РПЦ.

\section{СПИСОК ЛИТЕРАТУРЫ:}

1. Государственный архив Ульяновской области (далее - ГАУО). Ф. 768. Оп. 1. Д. 35. Л. 15.

2 ГАУО. Ф. 768. Оп. 1. Д. 47. Л. 59.

3. Сысоева Е. Образовательная политика в России (60-90 годы ХІХ века) // Педагогика. 1997. № 2.

4. Положение о начальных народных училищах. Свод законов. Т. 3. Ст. 1.

5. Юмакулов Н.Х. Система образования нерусских народов Среднего Поволжья: структура, организация, практика: дис. ... канд. пед. наук. Чебоксары, 2002. 225 с.

6. ГАУО. Ф. 135. Оп. 1. Д. 7. Л. 2-3.

7. ГАУО. Ф. 135. Оп. 1. Д. 65. Л. 8-8 об.

8. ГАУО. Ф. 99. ОП. 1. Д. 1182. Л. 4 об.

9. ГАУО. Ф. 99. Оп. 1. Д. 298. Л. 27 об.

10. Суперанский М.М. Начальная народная школа в Симбирской губернии. Историко-статистический очерк. Симбирск, 1906. С. 57.

11. Анастасиев А.И. Народная школа. Руководство для учителей и учительниц начальных народных училищ. Настольная справочная книга. 10-е изд. М.: Изд-во А.Д. Ступина, 1913. С. 230.

12. ГАУО. Ф. 190. Оп. 4. Д. 56. Л. 16.

13. Деятельность Симбирского земства по народному образованию (1866-1906 гг.) // ЖМНП. 1908. № 9 .

14. Захарьевский П.И. Церковные школы Казанской епархии за 25 лет их существования (18841909): Историко-статистический очерк. Казань: Центральная типография, 1909. 66 с.

15. Износков И.А. Собрание сведений о состоянии школьного дела в уездах Казанской губернии. Приложение к докладу Комиссии по народному образованию XIX экстренному Казанскому губернскому земскому собранию. Казань: Тип. М.А. Гладышевой, $1882.38 \mathrm{c.}$

16. Кеппен П.И. Об этнографической карте Европейской России. 2-е изд. СПб.: Императорское Рус. геогр. о-во, 1853. 40 с.

17. Краткий исторический очерк церковных школ Симбирской епархии. Составил протоиерей Дмитрий Троицкий. Симбирск: Тип. И.П. Балакирщева, 1907. $177 \mathrm{c}$

18. Материалы для географии и статистики России, собранные офицерами генерального штаба Симбирской губернии, часть 1,2 , составил генерального штаба полковник Липинский. СПб., 1868. 392 с.

19. Мельников В.П. Государственные органы и государственная служба в России: опыт организации и функционирования. Н.Новгород, 1995. 105 с.

20. Айзатуллова А.Ш. Религиозно-просветительская политика Российского государства в Средневолжском крае второй половины XIX - начала XX в. (на материалах Среднего Поволжья): монография. Ульяновск: УВАУ ГА(И), 2012. 112 с. 


\title{
PUBLIC AUTHORITIES' ROLE IN PUBLIC EDUCATION ORGANIZATION IN THE SIMBIRSK PROVINCE IN THE SECOND HALF OF THE 19TH CENTURY
}

(C) 2017

\author{
Aizatullova Alsu Shamilievna, candidate of historical sciences, \\ associate professor of Humanities and Social Sciences Department \\ Ulyanovsk Institute of Civil Aviation named after Chief Marshal of Aviation B.P. Bugaev \\ (Ulyanovsk, Russian Federation)
}

\begin{abstract}
This paper examines public authorities' role in public education organization in the Simbirsk province in the second half of 19th - beginning of the 20th century. The state structures, the Russian Orthodox Church and other confessions managed the state-religious education in the country. The author examines the role of public authorities in the organization of state-religious education of people. The Ministry of National Education and the Holy Synod were responsible for it on the state scale. In the provinces this work was coordinated by the guardianship of the school districts, directorate of education and provincial and district councils. In secular educational institutions educational work was organized by the directorate of public schools, who controlled the educational work of school teachers and effective forms and methods use. The main responsibility of the national education directorates was joint Russian-Tatar schools opening, Russian classes opening in Islamic schools and compulsory Russian language study in Tatar schools. An important goal was to tighten control over the school activities. There was Orthodox missionary fraternity. These organizations were responsible for the same questions. Provincial directorates of national education had to coordinate all state-religious activities done by teachers, religious priests and missionaries. Thus, the system of the state-religious education management was complex, diverse; its parts copied each other, so it led to its activity efficiency decrease.

Keywords: education; provincial directorate; Holy Synod; loyal spirit; state government; ministry of education; guardianship school districts; provincial and district school councils; diocese; denominations; directorate of national education; parish; secular schools; Orthodox missionary fraternity.
\end{abstract}

УДК $323.3(470)$

\section{ВСЕРОССИЙСКИЙ СОЮЗ РАВНОПРАВИЯ ЖЕНЩИН В БОРЬБЕ ЗА ВСЕОБЩЕЕ ИЗБИРАТЕЛЬНОЕ ПРАВО В 1905-1907 ГОДАХ}

(C) 2017

Банникова Наталия Федоровна, кандидат исторических наук, профессор кафедры философии и истории Миняшев Виктор Сергеевич, аспирант кафедры философии и истории

Самарский национальный исследовательский университет имени академика С.П. Королёва

(2. Самара, Российская Федерачия)

Аннотация. В статье рассматривается вопрос о политической активности российского общества в начале XX века. Важным направлением этого процесса было усиление женского движения, которое стремилось расширить гражданские и политические права. Показана позиция оппозиционных партий: кадетов, социалдемократов, эсеров, трудовиков, народных социалистов, выступавших за женское избирательное право. В годы первой русской революции появляются новые общественные организации, среди которых видное место занимает Всероссийский союз равноправия женщин. Рассказывается история основания союза. Показаны основные формы работы союза в борьбе за избирательное право для женщин: участие в митингах и собраниях, подготовка петиций и листовок, агитационно-пропагандистская работа, сбор наказов среди крестьянок. Особое внимание уделено агитационной работе членов союза. Показана статистика подписей, собранных под наказами в Государственную Думу с требованием женского избирательного права по отдельным регионам России. Выделены контакты Всероссийского союза равноправия женщин с думской оппозицией, особенно с фракцией социалистических партий и конституционными демократами, показано их тесное взаимодействие. Указаны конкретные депутаты Государственной Думы, наиболее активно сотрудничавшие с Всероссийским союзом равноправия женщин.

Ключевые слова: борьба за женское избирательное право; Всероссийский союз равноправия женщин; Государственная Дума Российской империи; избирательная компания в I Государственную Думу; избирательная компания во II Государственную Думу; партия народной свободы; первая российская революция; социал-демократическая фракция.

Женское движение в России стало активно развиваться в годы революционных потрясений в начале $\mathrm{XX}$ столетия. В это время в стране формировались многие общественные организации, в том числе женские. До 1905 года женщины в основном выступали за доступ к высшему образованию и профессиональному труду, теперь они включились в борьбу за политические права. В исторической литературе дея- тельность Всероссийского союза равноправия женщин (ВСРЖ) исследована недостаточно. ВСРЖ был первой организацией, которая боролась за предоставление избирательных прав женщинам, за активное участие в решении социальных вопросов.

В период разработки избирательного закона в начале 1905 года членами ВСРЖ была подготовлена и распространена листовка, в которой они обраща- 